\title{
Pemberdayaan Ekonomi Melalui Pemanfaatan Kulit Manggis (Teh Ekstrak Kulit Manggis) di RW 04 Desa Sumurugul
}

\author{
Nina Kurniasih'1, Riany Laila Nurwulan² \\ Jurusan Kesejahteraan Sosial, FISIP Universitas Pasundan \\ ınina.kurniasih@unpas.ac.id, 2riany.lailanurwulan@unpas.ac.id
}

\begin{abstract}
Abstrak
Salah satu fokus praktek profesi pekerjaan sosial adalah mengembalikan dan meningkatkan keberfungsian sosial melalui Community Development atau Community Organization yang melibatkan masyarakat secara langsung. Permasalahan utama di kalangan masyarakat Desa Sumurugul, khususnya di RW 04 adalah permasalahan sampah, kurangnya minat untuk bergotong royong, dan masalah keterbatasan dalam pengembangan usaha ekonomi kreatif. Kendala yang dihadapi oleh masyarakat di RW 04 berupa terbatasnya modal usaha, SDM yang kurang dalam pengembangan keterampilan serta keterbatasan pemasaran hasil usaha ekonomi kreatif. Masalah sosial yang terjadi di RW 04 Desa Sumurugul ialah masalah pengelolaan sumber daya alam berupa kulit manggis menjadi produk inovatif sebagai masalah utama. Berdasarkan permasalahan tersebut, program yang dipilih untuk dilakukan ialah "Sosialisasi Cara Pembuatan Kulit Manggis Menjadi Teh". Metode yang digunakan dalam pelaksanaan program yang telah direncanakan adalah Community Development, dengan metode pengembangan masyarakat lokaliti ini dalam tahap perencanaan, pelaksanaan, pengawasan, evaluasi dan tindak lanjut masyarakat RW 04, potensi serta sistem sumber yang ada di masyarakat RW 04 Desa Sumurugul. Hasil yang telah dicapai dalam pelaksanaan program tersebut yaitu meningkatnya kesadaran dan peran serta masyarakat RW 04 Desa Sumurugul dalam meningkatkan sumber daya alam dan mampu berdaya dalam membuat teh ekstrak kulit manggis secara mandiri.
\end{abstract}

Kata Kunci: Pemberdayaan, Ekonomi, Kulit Manggis

\begin{abstract}
One focus of the professional practice of social work is to restore and improve social functioning through Community Development or the Community Organization which directly involves the community. The main problems among the Sumurugul Village community, especially in RW 04 are waste problems, lack of interest in mutual cooperation, and problems of limitations in developing creative economic enterprises. The constraints faced by the community in RW 04 were limited business capital, human resources lacking in skills development and limited marketing results of creative economic efforts. The social problem that occurred in $R W 04$ of Sumurugul Village was that the problem of managing natural resources in the form of mangosteen peel became innovative products as the main problem. Based on these problems, the program chosen to be carried out was "Socialization of How to Make Mangosteen Skin into Tea". The method used in the planned program implementation is Community Development, with the local community development method in the planning, implementation, supervision, evaluation and follow-up stages of the community of $R W 04$, the potential and the source system in the community of $R W 04$, Sumurugul Village. The results achieved in the implementation of the program are increasing awareness and participation of $R W 04$ in Sumurugul Village community in improving natural resources and able to empower themselves to make mangosteen peel extract tea independently.
\end{abstract}

Key Words: Empowerment, Economy, Mangosteen Skin 


\section{PENDAHULUAN}

Pekerja sosial merupakan suatu profesi pertolongan atau pelayanan pertolongan secara professional yang berdasarkan pada konsep kesejahteraan sosial. Selain itu konsep kesejahteraan sosial merupakan suatu program yang terorganisir dan sistematis. Fokus utama dari kesejahteraan sosial yaitu membantu orang untuk memenuhi kebutuhan-kebutuhan dasarnya dengan cara memungkinkan orang agar dapat menjalankan fungsi sosialnya.

Definisi kesejahteraan sosial menurut Suharto (2010:1) sebagai berikut:

Kesejahteraan sosial adalah suatu institusi atau bidang kesejahteraan sosial yang melibatkan aktivitas terorganisir yang diselenggarakan baik oleh lembagalembaga pemerintah maupun swasta yang bertujuan untuk mencegah, mengatasi atau memberikan kontribusi terhadap pemecahan masalah sosial dan peningkatan kualitas hidup individu, kelompok, dan masyarakat.

Definisi di atas dapat pahami bahwa kesejahteraan sosial merupakan suatu sistem yang berisikan pelayanan sosial dimana sistem tersebut memberikan rasa sejahtera kepada individu, kelompok, maupun masyarakat untuk mencapai tingkat kesejahteraan yang lebih baik. Keadaan sosial yang sejahtera adalah setiap masing-masing individu merasakan terpenuhinya kebutuhankebutuhan hidupnya baik itu secara psikis, fisik, dan sosial untuk dapat melakukan sesuai dengan perannya masing-masing.

Pengabdian pada masyarakat ini dilaksanakan di Desa Sumurugul, Kecamatan Wanayasa, Kabupaten Purwakarta, Jawa Barat. Dari hasil FGD (Focus Group Discussion) yang laksanakan di RW 04, tim pengabdi mendapat masalah yang ada di RW o4 tersebut yaitu permasalahan sampah, kurangnya minat untuk bergotong royong, dan masalah keterbatasan dalam pengembangan usaha ekonomi kreatif. Kendala yang dihadapi oleh masyarakat di RW 04 berupa terbatasnya modal usaha, SDM yang kurang dalam pengembangan keterampilan serta keterbatasan pemasaran hasil usaha ekonomi kreatif. Fokus utama yang diangkat oleh tim pengabdi dalam membuat intervensi fokus yaitu pemberdayaan sumber daya alam yang ada di desa tersebut. Dari hasil FGD tim pengabdi tidak hanya menemukan masalah sosial tetapi tim pengabdi juga menemukan potensi yang ada di RW 04.

Salah satu potensi yang dapat tim pengabdi kembangkan untuk mengatasi permasalahan yang ada di RW 04 ini adalah banyak terdapat kelompok usaha yang berkembang di kalangan masyarakat Desa Sumurugul, khususnya di RW 04. Adapun kelompok usaha yang telah berkembang dan berjalan di masyarakat Desa Sumurugul seperti usaha kue tradisional, gula aren, dan pengepul buah manggis. Dengan banyaknya bermunculan kelompok usaha di Desa Sumurugul ini, diharapkan dapat meningkatkan kemampuan masyarakat Desa Sumurugul dalam memanfaatkan sistem sumber yang ada di sekitarnya yang meliputi sumber daya manusia, sumber daya alam dan juga sumber kelembagaan yang dapat menyokong berkembangnya kelompok usaha yang sedang mereka jalankan.

Menurut Sariningsih dalam jurnal (Kontingensi Volume 3, No. 2, Hal. 76-89 ISSN 2088-4877, Nopember 2015) menyatakan bahwa:

Kewirausahaan merupakan salah satu cara untuk mengatasi fenomena kemiskinan di Indonesia sebagai dampak dari krisis ekonomi yang berkepanjangan.

Pengembangan usaha yang ada di Desa Sumurugul mampu memberikan kontribusi yang relevan untuk menanggulangi masalah kemiskinan khususnya di kalangan masyarakat Desa Sumurugul. Pengembangan usaha ini tentu diperlukannnya berbagai dukungan berupa sumber daya manusia, dan dukungan dari pihak pemerintahan Desa Sumurugul. Dukungan yang diberikan berupa modal usaha yang dimana masyarakat dengan mudah memperoleh dana dalam proses pengembangan usaha ekonomi kreatifnya. Dengan adanya dukungan dari pemerintah desa mampu memberdayakan masyarakatnya dalam mengembangkan kewirausahaannya.

Melihat potensi yang ada di Desa Sumurugul, tim pengabdi berusaha untuk menemukan intervensi yang dapat membantu masyarakat dalam mengembangkan potensi yang ada di masyarakat. 
Tim pengabdi berusaha mengkaji tentang bagaimana kemampuan masyarakat Desa Sumurugul dalam memanfaatkan sumber daya manusia, sumber daya alam, dan kelembagaan dalam mengembangkan usaha yang ada di Desa Sumurugul tersebut. Atas dasar pemaparan di atas tim pengabdi terdorong untuk mengadakan pengabdian masyarakat mengenai Pemberdayaan Ekonomi melalui Pemanfaatan Kulit Manggis (Teh Ekstrak Kulit Manggis) di RW o4 Desa Sumurugul, Kecamatan Wanayasa Purwakarta.

\section{METODE PELAKSANAAN}

Metode yang digunakan dalam pelaksanaan program yang telah direncanakan adalah Community Development, dengan metode pengembangan masyarakat lokal ini ditujukan agar masyarakat mampu berpartisipasi secara aktif dalam kegiatan yang diselenggarakan. Dalam pelaksanaannya tim pengabdi bekerja sama dengan sistem sumber yang ada di wilayah kegiatan pengabdian pada masyarakat seperti pemerintah Desa Sumurugul dan Badan Usaha Milik Desa (BUMDES).

Kelompok sasaran pada program sosialisasi dan pelatihan pengolahan kulit manggis menjadi produk inovatif teh ekstrak kulit manggis adalah perwakilan masyarakat RW o4 yang meliputi aparatur RW 04, tokoh masyarakat dan ibu rumah tangga. Hal ini dimaksudkan agar pemberian sosialisasi dan pelatihan mampu berjalan efektif dan perwakilan masyarakat tersebut mampu menjadi penggerak di wilayahnya masing-masing. Kelompok sasaran program pengabdian kegiatan belajar dan mengajar adalah anak-anak siswa sekolah dasar dan menengah pertama.

Program atau kegiatan yang telah disusun sesuai dengan rencana yang dibuat dan telah disepakati oleh masyarakat RW o4 dan dilaksanakan di wilayah RW 04 meliputi program sosialisasi dan pelatihan pemanfaatan kulit manggis menjadi produk inovatif teh ekstrak kulit manggis yang dilaksanakan di rumah ketua RW o4 yang diikuti oleh perwakilan masyarakat RW o4 yaitu, aparatur RW 04, tokoh masyarakat dan ibu rumah tangga. Selain itu, program pengabdian kegiatan belajar dan mengajar dilaksanakan di Sekolah Dasar Negeri
Sumurugul dan Sekolah Menengah Pertama Satu Atap (SATAP) Sumurugul.

Bentuk pelaksanaan yang dilakukan berdasarkan program kegiatan yang telah direncanakan adalah program sosialisasi dan pelatihan pemanfaatan kulit manggis menjadi produk inovatif teh ekstrak kulit manggis dilaksanakan dalam waktu 1 hari. Bertempat di rumah ketua RW 04 dan dihadiri oleh perwakilan masyarakat RW 04 meliputi aparatur RW 04, tokoh masyarakat dan ibu rumah tangga. Tim pengabdi bertugas sebagai pemateri dalam pelaksanaan sosialisasi dan pelatihan ini. Materi disampaikan sekaligus memberikan pelatihan terkait pengolahan kulit manggis. Program pengabdian kegiatan belajar dan mengajar berlangsung selama lebih kurang 2 minggu. Tim pengabdi bertugas untuk memberikan mata pelajaran yang terkait yang bekerjasama dengan guru yang bersangkutan.

\section{HASIL DAN PEMBAHASAN}

Hasil dari pengabdian pada masyarakat yang telah dilakukan oleh tim pengabdi antara lain meningkatnya kesadaran masyarakat RW 04 Desa Sumurugul dalam pemanfaatan potensi sumber daya alamnya salah satunya buah manggis, serta menciptakan sebuah produk inovatif dari pemanfaatan pengolahan kulit manggis menjadi teh ekstrak kulit manggis, yang diharapkan dalam jangka waktu yang panjang akan menjadi sebuah produk yang mampu menjadi penggerak roda perekonomian khususnya masyarakat RW 04 dan Desa Sumurugul pada umumnya.

Dari hasil pengabdian terdapat beberapa hal yang perlu di evaluasi yakni kesadaran masyarakat yang masih kurang dalam memanfaatkan potensi sumber daya alam yang dimiliki salah satunya buah manggis, juga kurangnya inisiatif masyarakat dalam mengolah potensi yang ada dikarenakan masyarakat kurang mandiri dan hanya berharap pada bantuanbantuan yang digelontorkan oleh pemerintah. Selain itu juga belum optimalnya upaya pemerintah dalam menggerakan masyarakat agar mampu mandiri dalam mengelola potensi yang dimiliki.

Pelaksanaan program yang dilakukan di RW 04 selama satu bulan dapat dianalisis bahwa kekuatan terbesar di RW 04 adalah potensi. Potensi yang dimiliki pada sumber daya alam sangat 
berpengaruh besar terhadap kemajuan masyarakat di RW 04 karena potensi yang ada menjadi sebuah mata pencaharian utama masyarakatnya dan menjadi satu-satunya penghidupan di lingkungan tersebut. Potensi yang dimiliki di bidang sumber daya alam yaitu di sektor pertanian. Desa Sumurugul secara grafis memiliki wilayah yang kaya dan subur menjadikan potensi sumber daya alam dalam sektor pertanian melimpah. Sektor tersebut meliputi sawah, perkebunan teh, cengkeh, gula aren, buah pala dan buah manggis.

Berdasarkan analisis kami, kelemahan yang ada di RW 04 adalah sinergitas antara masyarakat dengan pemerintah Desa Sumurugul menjadikan masyarakat yang belum mampu mengoptimalkan potensi yang dimilikinya. Masyarakat belum sadar berbagai pembaharuan yang ada sehingga masih menjalankan segala sesuatu dengan pengetahuan terbatas yang dimilikinya.

Melihat potensi yang dimiliki oleh masyarakat RW 04 tentu ada kesempatan besar yang dapat dimanfaatkan untuk memajukan masyarakat. Pembekalan-pembekalan mengenai pengelolaan potensi yang baik dan inovatif akan memberikan hasil dimana masyarakat mampu mengoptimalkan potensi sumber daya alam yang dimiliki. Dampak lain yang akan dirasakan masyarakat adalah masyarakat mampu mandiri, menciptakan lapangan pekerjaan dan mencapai titik kesejahteraan.

Kekuatan terbesar RW 04 adalah potensi sumber daya alamnya. Jika tidak dimanfaatkan dengan baik tentu akan mengancam para petani yang merupakan mata pencaharian utama masyarakat RW 04. Jika potensi ini belum mampu dimanfaatkan dengan baik oleh pemerintah kemungkinan besar akan dampak yang akan ditimbulkan adalah masyarakat yang tidak akan mampu mandiri dan sulit untuk mencapai tingkat kesejahteraan.

Rekomendasi yang ingin kami sarankan sebagai bentuk perbaikan kepada pihak aparatur Desa Sumurugul adalah lebih memperhatikan wilayah RW 04 seperti infrastrukur, penyediaan alat produksi dan pemanfaatan potensi sumber daya alam untuk kemajuan para petani dengan melakukan penyuluhan dan sosialisasi berkala serta meningkatkan kesadaran masyarakat RW 04 dengan kebijakan-kebijakan yang dibuat untuk meningkatkan kemandirian masyarakat untuk memenuhi kebutuhan dasarnya.
Berdasarkan hasil pengabdian yang sudah dilakukan, tim pengabdi merumuskan tindak lanjut dari aspek-aspek yang dijadikan rujukan sebagai berikut :

a. Potensi sumber daya alam yang terbengkalai karena tidak dimanfaatkan sepenuhnya oleh masyarakat RW 04.

b. Pengetahuan yang rendah mengenai pengelolaan pertanian yang dialami oleh masyarakat RW 04.

c. Rendahnya inisiatif masyarakat dalam pemanfaatan potensi yang berpengaruh pada kemandirian masyarakat.

Tim pengabdi membuat rujukan dengan tujuan untuk meningkatkan kemandirian masyarakat dengan memanfaatkan potensi sumber daya alam secara inisiatif dan pemanfaatan potensi sumber daya alam yang ada secara maksimal dengan tujuan menciptakan petani sejahtera. Pihak-pihak terkait yang tim pengabdi jadikan rujukan, yaitu :

a. Pemerintah Desa Sumurugul

Pemerintah Desa Sumurugul sebagai pembuat kebijakan masyarakat diharapkan mampu mengeluarkan kebijakan-kebijakan yang bertujuan pada optimalisasi potensi yang dimiliki masyarakat. Perlu ada pembaharuan, ide kreatif agar potensi yang dimiliki masyarakat tidak tersia-siakan.

b. Badan Usaha Milik Desa (BUMDES)

Badan Usaha Milik Desa yang bertujuan untuk mengembangkan sektor usaha kecil dan menengah masyarakat diharapkan mampu mendatangkan ide-ide kreatif khususnya dibidang pemasaran produk agar potensi masyarakat mampu optimal.

c. Aparatur RW 04

Sebagai tokoh masyarakat aparatur RW 04 berperan penting dalam menciptakan sebuah kondisi masyarakat yang terus giat dan semangat dalam menjalankan aktivitas khususnya dibidang pengelolaan potensi sumber daya alam. Hal ini bertujuan agar masyarakat tetap terjaga semangat dan gotong royong dalam menjalankan setiap aktivitasnya. 


\section{KESIMPULAN DAN SARAN}

\section{Kesimpulan}

Permasalahan sosial yang terjadi di RW 04 Desa Sumurugul ialah masalah pengelolaan sumber daya alam berupa kulit manggis menjadi produk inovatif sebagai masalah utama. Dengan itu, program yang dipilih untuk di jalankan ialah "Sosialisasi Cara Pembuatan Kulit Manggis Menjadi Teh". Berdasarkan hasil FGD tim pengabdi melakukan perencanaan bersama masyarakat Desa Sumurugul untuk membuat beberapa program untuk mengatasi permasalahan yang ada di RW o4 yaitu produk inovatif ekstrak kulit manggis.

Metode yang digunakan dalam pelaksanaan program yang telah direncanakan adalah Community Development, dengan metode pengembangan masyarakat lokaliti ini dalam tahap perencanaan, pelaksanaan, pengawasan, evaluasi dan tindak lanjut masyarakat RW 04, potensi serta sistem sumber yang ada di masyarakat RW 04 . Dalam pelaksanaan program yang tim pengabdi laksanakan bersama masyarakat RW 04, bekerja sama dengan sistem sumber yang terkait yaitu Tokoh masyarakat, Ketua RW 04. Hasil yang telah dicapai dalam pelaksanaan program tersebut yaitu meningkatnya kesadaran dan peran serta masyarakat RW 04 Desa Sumurugul dalam meningkatkan sumber daya alam yang ada dan mampu berdaya dalam membuat teh ekstrak kulit manggis secara mandiri.

\section{Saran}

Terdapat beberapa saran yang dapat tim pengabdi berikan kepada masyarakat mengenai pemanfaatan potensi yang dimiliki oleh masyarakat di wilayah RW 04 meliputi:

a. Pemerintah Desa Sumurugul, sistem sumber terpenting dalam lingkup desa yang dapat mewadahi aspirasi masyarakat desa serta memberikan dukungan melalui kebijakankebijakan yang dibuat untuk kesejahteraan masyarakat desa.

b. Pemerintah Kecamatan Sumurugul, peran dari pihak Desa Sumurugul sangat penting untuk memajukan dan mengembangkan potensi sumber daya alam salah satunya buah manggis dan dijadikan teh ekstrak kulit manggis. c. Badan Usaha Milik Desa (BUMDES), sebagai sistem sumber yang berfungsi menjadi penggerak dalam usaha-usaha kecil menengah di Desa Sumurugul.

d. Masyarakat RW 04, sebagai sistem sumber terpenting masyarakat berperan sebagai pengolah potensi yang dimilikinya. Hal ini dimaksudkan agar masyrakat mampu menjaga semangat kebersamaan dan gotong royong dalam menjalankan segala aspek kehidupannya demi mencapai tingkat kesejahteraan yang ideal.

\section{DAFTAR REFERENSI}

Sariningsih. (2015). Jurnal Kontingensi, 3 (2), 7689.

Suharto, Edi. (2010). Membangun Masyarakat Memberdayakan Rakyat: Kajian Strategis Pembangunan Kesejahteraan Sosial \& Pekerjaan Sosial. Menulis artikel untuk jurnal pengabdian kepada masyarakat. Bandung: Refika Aditama. 